\title{
Foreign Animation Films and the Rising of Anti-Multiculturalism among Parents
}

\author{
Leslie Retno Angeningsih ${ }^{1 \varpi}$ and Nuraini Dwi Astuti ${ }^{1}$ \\ ${ }^{1}$ The Institute of Community Development "APMD” Yogyakarta, Indonesia
}

Permalink/DOI: http://dx.doi.org/10.15294/komunitas.v6i2.3309

Received : July 2014; Accepted: August 2014; Published: September 2014

\begin{abstract}
As the impact of globalization, foreign animation films such as Shin Chan from Japan, Krishna from India, UpinIpin from Malaysia, Batman and many others from the US are very popular in Indonesia. Those films supposed represent cultures of each nation, so that people can learn multiculturalism. However, those films create inversely. This study aims to know how foreign animation films affect on the rising of anti-multiculturalism among Indonesian parents. Survey is conducted on parents with kindergarten or elementary children in Yogyakarta. The results show that children prefer to watch foreign animation films compare to domestic one. They are more likely to imitate their favorite animation stars by behaving violently, speaking harshly, and disrespectfully to parents. As a result parents tend to blame their children changing behavior on foreign cultures as bad and impolite compare to their own culture. Instead of encouraging better understanding on multiculturalism, foreign animation films has raised anti-multiculturalism among parents.
\end{abstract}

\begin{abstract}
Abstrak
Sebagai dampak globalisasi, film animasi asing seperti Shin Chan dari Jepang, Krishna dari India, Upin Ipin - dari Malaysia, Batman dan banyak lainnya dari Amerika Serikat sangat populer di Indonesia. Film-film seharusnya mewakili budaya masing-masing negara, sehingga orang dapat belajar multikulturalisme. Namun, film-film ini dapat pula berakibat sebaliknya. Penelitian ini bertujuan untuk mengetahui bagaimana film animasi dari luar bisa berpengaruh pada peningkatan anti-multikulturalisme pada orang tua di Indonesia. Survey dilakukan pada orang tua yang memiliki anak TK atau SD di Yogyakarta. Hasil menunjukkan bahwa anak-anak lebih memilih untuk menonton film animasi asing dibandingkan dengan film dalam negeri. Mereka lebih cenderung untuk meniru bintang animasi favorit mereka dengan berperilaku keras, berbicara kasar, dan tidak hormat kepada orang tua. Akibatnya, orang tua cenderung menyalahkan anak-anak mereka perilaku yang berubah pada budaya asing sebagai buruk dan tidak sopan dibandingkan dengan budaya mereka sendiri. Alih-alih mendorong pemahaman yang lebih baik tentang multikulturalisme, film animasi asing telah meningkatkan anti-multikulturalisme di kalangan orang tua.
\end{abstract}

Keywords: culture; socialization; ethnocentrism; anti-multiculturalism

How to Cite: Angeningsih, L.A., Astuti, N.D. 2014. Foreign Animation Films and the Rising of AntiMulticulturalism among Parents. Jurnal Komunitas, 6(2):303-311. doi:http://dx.doi.org/10.15294/komunitas. v6i2.3309

(c) 2014 Semarang State University. All rights reserved 


\section{INTRODUCTION}

Television programs for kids are closely related to animation or cartoon films. In the United States, animation films have entertained children for over 80 years. Felix the Cat was very popular in the 1920s. Mickey Mouse, Donald Duck, and Pluto have become international idols in the 1930s. By the 1950s, Popeye the Sailor was attracting a number of television audiences followed by the Flinstones. Since 1999, Sponge Bob Squarepants has been on the air on Nickelodeon. Currently, the foreign animation films such as Tom and Jerry, Doraemon, Sponge Bob, Nickoledeon, The Antz, Toy Story, and Bernard Bear become so popular among kids (Kirsh, 2006). In Asia, the film industries also produced animation films such as Naruto and Crayon Sin Chan (Japan), Khrisna (India), Upin-Ipin (Malaysia), and Si Unyil (Indonesia). With the growing of communication technology and the globalization of the media enable cartoon films to spread quickly around the world. By the incoming of foreign animation films to Indonesia, children are more likely to watch foreign animation films instead of domestic ones.

Animation films have long been criticized for influencing children. Many negative social phenomena involve children and adolescents who are likely to watch violence or non-comedy cartoons. Classical experiment found that violent cartoon does negatively influence preschool children (Bandura, et.al., 1963; Friedrich \& Stein, 1973; Lovass, 1961). Another study among 8th grade boys and girls showed that viewing of cartoon violence increases in minor acts of violence among boys but not for girls (Aluja-Fabregat \& Torrubia-Beltri, 1998; Cantor \& Wilson, 2003). Older children imitate aggression to a lesser extent than younger children as a result of older children have better impulse control than younger children (DeHart et al., 2004; Nathanson \& Yang, 2003, Wilcox, 2004). Children become less sensitive to the pain and suffering of others, do not fear violence nor are they bothered by violence and become more aggressive towards others (Leu, 2004). Additionally, children who watch too much cartoons are more likely to have mental and emotional problems, along with brain and eye injuries and unexpectedly the risk of a physical problem increases (Adams, 1992). For instance, Sponge Bob has an impact on children's morality because its use of metaphors in place of profanity. The Japanese cartoon "Pocket Monster" or "Pokémon" causes Muslim children in the Middle East, Turkish and Egypt forget about and ignore the obligation for praying (Warner, 2004).

Animation films that mostly show physical violence, murder scenes, sex, illusion and subliminal messages have made parents feel worry about the impact of cartoons in children. Consequently, parents start blaming children behavior problems on TV programs. Many studies have been conducted on the impact of animation films on children but very few that look at the impact of children changing behavior as a result of imitating their animation film stars on parents. This study aims to know how foreign animation films affect on the rising of anti-multiculturalism among Indonesian parents. The objectives of this study are to examine the most favorite animation films that children are more likely to watch and become their models. It also tries to understand the most hatred animation films which parents thought had an impact on their children behavior.

\section{LITERATURE REVIEW}

According to Velkley (2002) culture has two meaning as the folk-spirit having a unique identity, and culture as cultivation of inwardness or free individuality. The first meaning is predominant in our current use of the term "culture," although the second still plays a large role in what we think culture should achieve, namely the full "expression" of the unique of "authentic" self. Culture can be defined as the values the members of a given group hold, the norms they follow, and the material goods they create. Culture freed early humans from dependence on the instinctual and genetically determined set of responses to the environment characteristics of other species. Cultures in diffe- 
rent environments varied widely as a result of adaptations by which people fashioned their cultures to be suitable to specific geographic and climatic conditions. The concept of culture ties in ethnic group. Ethnic group is a group possessing a common cultural system with a high degree of cultural homogeneity. Ethnic group may have either majority or minority status in a given social system (Thomas, 1974). Indonesia consists of many ethnic groups with their own uniqueness culture. Javanese is the largest ethnic group in Indonesia with a long unique culture of monarchy roots.

\section{Socialization}

A particular cultural pattern is transferred from one generation to another through various forms of socialization and communication. Socialization refers to the process of inheriting norms, customs and ideologies. It may provide the individual with the skills and habits necessary for participating within their own society; a society develops a culture through a plurality of shared norms, customs, values, traditions, social roles, symbols and languages. Socialization is thus 'the means by which social and cultural continuity are attained' (Clausen, 1968:5). Socialization is the primary means by which human infants begin to acquire the skills necessary to perform as a functioning member of their society, and is the most influential learning processes one can experience (Billingham, 2007). Values are internalized as people encounter various agents of socialization. Attitudes and behaviors are learned within a social context where agents of socialization are important (Farley, 2000:2932).

Family is the primary agent of socialization besides media. Parents socialize children with their own culture. They have some investment in their children's future. The investment is likely to be emotional, financial, cultural, political, and placebound. Mass media is also significant as a social force for socialization. According to Dennis McQuail (2005:494):

"The media can teach norms and values
Jurnal Komunitas 6 (2) (2014): 303-311 305 by way of symbolic reward and punishment for different kinds of behavior as represented in the media...The media are continually offering pictures of life and models of behavior in advance of actual experience."

From films, video games, Television to news can teach both positive and negative norms and values. Children are surrounded by media that some will at the very least desensitize them. Violence can be found in animation films that may influence children to commit atrocities themselves. Such as, the Little Mermaid film who has her tongue cut out, almost stabs her prince, and dies; Disney's famous version of this classic tale is significantly happier and less violent (Laurie, 2011). On the other hand, The Lion King, gain an appreciation and receive positive reviews from critics its music and story. The character animators based on real-life animals for reference (The Lion King, 2011).

\section{Ethnocentrism}

Each ethnic group tries to socialize its own culture to the next generation, so that to some degrees can create ethnocentrism. According to Sumner (1906), ethnocentrism is related to in most inter group contexts, one's own group is the center of everything, and all other things are related to or dependent on. According to the Oxford English Dictionary, ethnocentrism is defined as regarding one's own race or ethnic group as of supreme importance. Ethnocentrism has been described as an individual psychological disposition which has positive and negative outcomes (Neuliep \& McCroskey, 1997). On the one hand, it serves as an antecedent towards patriotism and willingness to sacrifice for one's central group and helps in constructing and maintaining one's cultural identity (Chen \& Starosta, 2004). On the other hand, it leads to misunderstandings and reduced levels of intercultural-willingness-to-communicate (Lin \& Rancer, 2003). Ethnocentrism is also highly related to individuals' identity formation. Kim, Kim, and Choe (2006) reviewed identity's link to ethnocentrism as it relates to multicultural issues. 


\section{Multiculturalism and Ethnocentrism}

Andrew Heywood distinguishes between two forms of multiculturalism, descriptive and normative. As a descriptive term, multiculturalism refers to cultural diversity. As a normative term, it implies a positive endorsement, even celebration, of communal diversity, typically based on either the right of different groups to respect and recognition or to the alleged benefits to the larger society of moral and cultural diversity (Gerbner, 1972).

Multiculturalism differs from ethnocentrism. Multiculturalism is inclusive, whereas ethnocentrism is exclusive. In multiculturalism, we are enriched with multiple understandings precisely because we are expected to suppress none, or exclude anyone from participating. In ethnocentrism, especially when practiced in its extreme forms, outsiders are not only excluded, but often denigrated, or even means are found or speculated about on how to control them.

Multiculturalism in contemporary accelerated globalization is profoundly different from the past. According to Hannerz (1996) now there is a world culture or global multiculturalism. Multi-ethnicity exists worldwide and multiculturalism discourse and policy is spreading widely. New channels of communication and influence are taking shape. The globalization of the media enables rapid worldwide exposure of current events. Unfortunately, there are factors that hinder the advancement of multiculturalism. Media is one of these factors (Fleras \& Kunz, 2001).

\section{Anti-Multiculturalism}

Freemen (2002) argues that multiculturalism prescribes a policy not just of toleration, but also accommodation of disparate cultural groups, many of which do not endorse liberal social or even political norms. This belief leads many critics to argue that multiculturalism is nothing more than a philosophical justification for cultural relativism. Barry (2002) suggests that only liberal egalitarian principles can remain relevant in a theory of social justice because illiberal groups cannot ensure individual rights. The term anti-multiculturalism thus refers to the belief that difference can only be constructed and viewed in purely negative terms, and that minority cultures should not coexist alongside majority ones.

Globalizing processes rebound in the distribution, of wealth and poverty, of resources and impotence, of power and powerlessness, of freedom and constraint. Today the process of a world-wide restratification, in the course of which a new sociocultural hierarchy, a world-wide scale, is, put together (Bauman, 2004).

Anti-multiculturalism is a longstanding desire to preserve a myth of ethnic homogeneity and cultural uniqueness. For example, Japan has the concept of nihonjinron for anti-multiculturalism. They thought that other culture will contaminate a pure ethnic Japanese identity (Shipper, 2005). Sugimoto (1999) argues that nihonjinron, which is based on "racial classifications and the state ideology of integration," has been used to "not only mask ethnic minority issues in Japan but also its intra-national, nonethnic variations and conflicts." As a result, it has been used to preserve the "core of Japanese ness." In light of this preoccupation with Japanese identity, which continues to play out on several platforms of life, including graphic art, pop culture, and literature, politicians can exploit these assumptions about core identity in attacking foreigners. Each ethnic group in Indonesia has almost similar to that of Japanese concept, particularly for Javanese people. This principle affects to the way Javanese people judging other ethnic groups. Consequently, Javanese people being more likely prejudice to foreign.

Related to the globalization of mass media, the effect on prejudice of television and the movies is substantial. The media's portrayal of racial and ethnic groups may be a person's principal source of information. Therefore, if the media communicates primarily in stereotypes and the viewer has little opportunity for personal contact with members of that minority, the probability of the stereotype becoming the reality to the viewer is high. Hollywood movies have tho- 
roughly dehumanized the nonwhite world. The whites, who are the exploiters, consistently show up as the "good guys." Whites are portrayed as the bearers of civilization and all that is just and humane. Their superiority is taken as the natural order of things, and their "justified" extermination of the nonwhites provides a "happy" ending (Kitano, 1985:52).

Racism and stereotypes are propagated in the animation films such as Pocahontas. Pocahontas has been accused of inaccurately depicting Native-American life (Cortes, 2000). As the embedded racism, sexism and stereotyping in the Disney animation described, if not properly guided when watching these films, children can approach life with misinformed ideas without even being aware of it and perceive as actuality (Fleras and Kunz, 2001).

Perceived actuality is the degree to which a viewer perceives media depicted portrayals of events, settings, and characters as existing, or being able to exist, in the real world. The more a viewer believes that what they are seeing on TV or in movies could actually happen in real life, the higher the degree of perceived actuality. Perceived similarity refers to degree of similarity between the viewer and media-depicted events, settings, and characters. The more similarities perceived between the viewer's life and the content of the viewed media, the greater the level of perceived similarity (Potter, 2003). Anti-multiculturalism arises as the effect of terrifying parents on their children perceived actuality toward the films. Indonesian people or Javanese people in particular, are very rigorous on the incoming foreign animation films that will affect children enculturation.

\section{METHODS}

A cross-sectional survey was conducted on 258 parents with kindergarten or elementary children from 5 regions in the Special Province of Yogyakarta (DIY) and outside Yogyakarta, Indonesia. Using questionnaires, parents were interviewed about their opinion on foreign animation films and multiculturalism. The children were asked about their activities and preferences on foreign animation films. This study used purposive random sampling. As the dependent variables were binary, the data were analyzed using binary logistic regression.

\section{RESULTS AND DISCUSSION}

Majority the respondents are from the Region of Sleman $(55.8 \%)$. They are mostly males $(69.4 \%)$ and their ethnicity is Javanese $(96.1 \%)$. Majority of respondents are at the age of $36-40$ years old $(29.1 \%)$ with high school education (52.3\%), and work at private sectors (30.2\%). Their children also majority are males $(55.8 \%)$, at the age of $10-$ 11 years old $(28.7 \%)$. They are at grade sixth $(21.7 \%)$, and study at public elementary schools (46.5\%). Children mostly are the oldest child (53.1\%), with two siblings (35.3\%).

Related to leisure time, children mostly used it for playing with their siblings (27.1\%) and watching TV (24.4\%). The TV program that children likely to watch the most was cartoon $(52.7 \%)$, followed by the kids program (10.1\%). The foreign animation films that children like to watch the most were Upin-Ipin (55.8\%) and Sponge Bob (58.5\%). But for Shin Chan only 23.3\%, Nickoledeon (21.3\%), Tom and Jerry (37.6\%), Lion King (11.6\%), the Antz (7\%) and Toys Story (14\%). The reason children preferred to watch cartoon films because they are funny (44.6\%) and very interesting story (17.8\%).

Binary logistic regression results show that foreign animation films has positive relationship with parents who live in the City of Yogyakarta $(b=2.707$; $p<0.05)$ and parents who work at private sectors $(b=0.859$; $\mathrm{p}<0.05)$, meaning that parents who live in the City of Yogyakarta are 2.702 times more likely to have children who prefer to watch foreign animation films than parents who live outside Yogyakarta City. Parents who work at private sectors are 0.859 times more likely to have kids that prefer watching foreign animation films than parents having other jobs. Shin Chan has negative relationship with parents' sex $(b=-1.005 ; p<0.05)$, meaning that fathers are 1.005 less likely to have children who prefer to watch Shin Chan than mothers. 
Upin-Ipin has positive relationship with parents who live in the City of Yogyakarta $(b=1.599 ; \mathrm{p}<0.05)$ and has negative relationship with children's grade $(b=-0.461$; $\mathrm{p}<0.01$ ), meaning that parents who live in Yogyakarta city are 1.599 times more likely to have children who prefer to watch Upin-Ipin than children whose parents live outside Yogyakarta. On the other hand, children with higher grade are 0.461 less likely to watch Upin-Ipin than children with lower grade. Between Indonesian and Malaysian, there is similarity culture namely Malay culture. Malay culture can be found in the form of language. The story presented by Upin-Ipin is closely related to the Indonesian children daily life. Parents who live in Yogyakarta City are more likely able to speak Indonesian language which almost similar to that Malay language or Melayu compare to that of parents who live in the Regions. Thus, it is not surprising that Upin-Ipin is very common for family in the Yogyakarta.

Nickoledeon has negative relationship with Javanese parents $(\mathrm{b}=-1.430 ; \mathrm{p}<0.05)$ and has positive relationship with total siblings $(b=0.460 ; p<0.05)$, meaning that Javanese parents are 1.430 times less likely to have children who prefer to watch Nickoledeon than non-Javanese parents. Children who have siblings are 0.460 times more likely to watch Nickoledeon than children with no siblings. Javanese people are known as the one polite, gentle ethnic group in Indonesia, thus they are less likely to allow children to watch films that considered inappropriate. Children with sibling are more likely to watch Nickoledeon than children with no sibling. This is because watching that kind of film is more attractive if we have friends.

Doraemon has positive relationship with parents who live in the City of Yogyakarta $(\mathrm{b}=4.850 ; \mathrm{p}<0.001)$, meaning that parents who live in Yogyakarta city are 4.850 times more likely to have children who prefer to watch Doraemon than children whose parents live outside Yogyakarta.

Sponge Bob has positive relationship with parents who live in the Region of Sleman $(b=1.326 ; p<0.01)$ and parents' occupation at private sectors and government employees $(b=0.746 ; p<0.05)$ and $(b=1.654$; $\mathrm{p}<0.001)$ consecutively, meaning that parents who live in the Region of Sleman are 1.326 times more likely to have children who prefer to watch Sponge Bob than children whose parents live outside Yogyakarta. Parents who work at private sectors and being government employees are 0.746 times and 1.654 times consecutively, more likely to have children who prefer to watch Sponge Bop than children whose parents having other jobs.

Tom and Jerry has negative relationship with children's grade $(b=-0.492 ; \mathrm{p}<0.01)$ and has positive relationship with children's age $(b=0.961 ; p<0.01)$, meaning that children with higher grade are 0.492 times less likely to watch Tom and Jerry than children with lower grade. But, with the age the result show inversely, means that older children are 0.961 times more likely to watch Tom and Jerry.

Lion King has positive relationship with children's sex $(b=1.219 ; \mathrm{p}<0.01)$ and total siblings $(\mathrm{b}=0.607 ; \mathrm{p}<0.05)$, meaning that boys are 1.219 times more likely to watch the Lion King than girls and children with siblings are 0.607 times more likely to watch the Lion King than children with no siblings.

The Antz has negative relationship with children number $(b=-1.091 ; p<0.05)$ and has positive relationship with total siblings ( $b=0.699 ; p<0.05)$, meaning that the older children are 1.091 less likely to watch the Antz than the younger children but children with siblings are 0.699 more likely to watch the Antz than children with no siblings.

Toys Story has negative relationship with Javanese parents and parents' sex ( $b=-$ 1.598; $\mathrm{p}<0.05)$ and $(\mathrm{b}=0.982 ; \mathrm{p}<0.05)$ consecutively, meaning that Javanese parents are 1.598 times more likely to have children who prefer to watch Toys Story than children whose non-Javanese parents. Fathers are 0.982 less likely to have children who prefer to watch Toys Story than mothers. Toys Story is considered more violent, little bit creepy, scarier and intense for young kids and contain of consumerism. Though, there are wonderful, touching messages about friendship, and loyalty. 
Jurnal Komunitas 6 (2) (2014): 303-311 309

The binary regression on anti-multiculturalism show that parents' characteristics that have significant positive relationships with anti-multiculturalism are parents who live in Bantul $(b=2.297 ; p<0.01)$ and Sleman Regions ( $b=2.659$; $p<0.001)$, meaning that parents who live in Bantul and Sleman Regions are 2.297 times and 2.659 times consecutively, more likely against multiculturalism than parents who live outside Yogyakarta. In the children side, anti-multiculturalism is positively related to children age $(b=0.363 ; p<0.05)$, meaning that older children are 0.363 times more likely having anti-multiculturalism than younger children. Yogyakarta is the center of Javanese monarchy but it has already become moderate to modern culture. But, the Region of Bantul remains loyal to monarchy cultural system and they try to maintain the Javanese culture. On the other side, Sleman is the most educated Region because majority of people living at the area are educated people as many universities located in this region. They are very rational. They are able to think what is appropriate and inappropriate for them or their children. Consequently, they tend to be more anti-multiculturalism than other people toward everything that will overcome young generation, such foreign animation films. As children become older, they already socialized by Indonesian or Javanese culture. They are able to think about right and wrong. This result is similar to that of DeHart et.al. (2004) study, Nathan \& Young (2002) and Wilcox (2004).

Looking at the foreign animation films itself, the results show that Upin-Ipin has negative relationship with anti-multiculturalism $(b=-.0924 ; \mathrm{p}<0.05)$, meaning that children who prefer watching Upin-Ipin are 0.924 times less likely having anti-multiculturalism than children who prefer other foreign animation films.

Regress all variables parents' and children characteristics and foreign animation films preferences together toward anti-multiculturalism, the result shows that parents who live in Bantul and Sleman Regions remain have positive relationship with anti-multiculturalism $\quad(\mathrm{b}=2.804 ; \mathrm{p}<0.001)$ and $(\mathrm{b}=3.048$; $\mathrm{p}<0.001)$ consecutively. Parents' age has negative relationship with anti-multiculturalism ( $b=-0.486 ; \mathrm{p}<0.05)$, meaning that older parents are 0.486 times less likely having anti-multiculturalism than younger parents. Older parents are more tolerance than younger parents because among Javanese older people still stick to traditional philosophy. Toys Story has positive relationship with anti-multiculturalism $(b=2.151 ; p<0.05)$, meaning that children who prefer watching toys story are $2.151 \mathrm{ti}$ mes more likely to have parents who are anti-multiculturalism than children who prefer watching other foreign animation films. Children's number has positive relationship on anti-multiculturalism ( $\mathrm{b}=0.862 ; \mathrm{p}<0.05)$, meaning that the oldest children are 0.862 times more likely having anti-multiculturalism than the youngest children. Toy Story is thought to be the one animation films that affecting parents against multiculturalism.

\section{CONCLUSION}

When we are born we have the capacity for motivation, experience, and training, and because of this our minds are very impressionable. Therefore, our brains' development is a dynamic mix of nature and nurture, so it is important to choose a healthy environment for all children. This means cartoons with stereotyping and discriminating or unreal will be unhealthy for not only a child but also adults because in general, will be judged as inappropriate or inferior to the representation of certain nation. As a result, media can limit social interaction and may obstruct the development of global multiculturalism. The ability to attain togetherness through animation films urges people of different origins and different bloods to acknowledge cultural identity as a means to transform society. Through animation films should be used for guiding society into another age of enlightenment. Thus, the animation films should be geared toward eliminating all forms of ethnocentrism such as religious and ideological prejudices, bigotry, and racial discrimination because without that first step toward togetherness, social change will continue to fail, and na- 
310 Leslie Retno Angeningsih et al., Foreign Animation Films and the Rising of Anti-Multiculturalism

tionalism will rise as a result of such cultural biases, allowing multiculturalism to be forgotten.

When parents choose what cartoons to let their children watch, they want to make sure that these cartoons are appropriate for general audiences. People who create popular cartoons are careful to not allow any unrealistic content to be incorporated into their cartoons. However, every cartoon can't be made perfectly safe for viewing by children and some of the verbal content may be mistaken for auditory subliminal messages.

By knowing the most preference foreign animation films for children, parents should keep close eyes on what their children watch and tell their children that the exposure is not really real. In order to encourage global multiculturalism, the film producers should consider the story that helps better understanding foreign culture as represent the real culture of that nation. Thus, the story will give similar perception to the audiences and not create prejudice based on ethnocentrism. In other words, the story can help to encourage integration, harmony in the relationship among nation in the era of globalization.

\section{REFERENCES}

Adams, C. 1992, July 24. Will sitting too close to the $\mathrm{TV}$, reading with bad light, etc., ruin your eyes? The Straight Dope. Retrieved November 3, 2004 from http://www.straightdope.com/classics/a5_105.html

Aluja-Fabregat, A., \& Torrubia-Beltri, R. 1998. Viewing of mass media violence, perception of violence, personality, and academic achievement. Personality and Individual Differences, 25, 973-989.

Bandura, A., Ross, D., \& Ross, S. A. 1963. Imitation of film-mediated aggressive models. Journal of Abnormal and Social Psychology, 66, 1, 3-11.

Banks, J.A., \& C.A.M. Banks, C.A.M. 1995. (Eds.). Handbook of research on multicultural education. (pp.3-24). New York: Macmillan.

Bauman, Z. 1998. Globalization: The Human Consequences (Themes for the 21st Century Series). London: Polity Press.

Barry, B. 2002. In Multiculturalism Reconsidered: Culture and Equality and its Critics. University Park, Penn.: Polity.

Billingham, M. 2007. Sociological Perspectives (p.336). In Stretch, B. and Whitehouse, M. (eds.). Health and Social Care Book 1. Oxford: Heinemann.

Cantor, J., \& Wilson, B. J. 2003. Media and violence: Intervention strategies for reducing aggression. Media Psychology, 5, 363-403.

Chen, G. M., \& Starosta, W.J. 200o. The development and validation of the international communication sensitivity scale. Human Communication, 3, 2-14.

Clausen, J.A. 1968. Socialization and Society, Boston: Little Brown and Company.

Cortes, C.E. 200o. The Children Are Watching: How the Media Teach About Diversity. New York: Teachers College Press.

DeHart, G. B., Sroufe, L. A., \& Cooper, R. G. 2004. Child development: Its nature and course $\left(5^{\text {th }}\right.$ ed). New York: McGraw Hill.

Fleras, A. \& Kunz J.L. 2001. Media and Minorities: Representing Diversity in a Multicultural Canada. Toronto: Thompson Educational Publishing.

Freemen, S. 2002. In Multiculturalism Reconsidered: Culture and Equality and its Critics. (p.19).University Park, Penn.: Polity, 2002, p. 19.

Friedrich, K. L., \& Stein, A. H. 1973. Aggressive and prosocial television programs and the natural behavior of preschool children. Monographs of the Society for Research in Child Development, 38, 1-110.

George, G. 1972. Violence in Television Drama: Trends and Symbolic Functions, in Television and Social Behavior: Media Content and Control.

Hannerz, Ulf. 1996. Transnational connections: culture, people, places. London: Routledge.

Kim, S., Kim, H, Choe, Y. 2006. An exploratory study on cultural differences between Koreans, Japanese, and Native speakers of English. Human Communication, 9, 57-70.

Kirsh, S. J. 2006. Children, adolescents, and media violence: A critical look at the research. Thousand Oaks, CA: Sage.

Laurie. 2011. The effects of violence in the media on children. Retrieved 30 Mei 2011 from http:// www.associatedcontent.com/article/5134/ the_effects_of_violence_ in_the_media_pg3. html?cat $=25$

Leu, R. 2004. Television's effects on the brain and eyes. November 15. TCOM.

Lin, Y., \& Rancer, A. S. 2003. Ethnocentrism, intercultural communication apprehension, intercultural dialogue program: Testing a proposed model. Communication Research Reports, 20, 62-72.

Lovass, O. I. 1961. Effect of exposure to symbolic aggression on aggressive behavior. Child Development, 32, 37-44.

Nathanson, A. I., \& Yang, M. 2003. The effects of mediation content and form on children's responses to violent television. Human Communication Research, 29, 11-124.

Neuliep, J. W. \& McCroskey, J. C. 1997. Development of a US and Generalized Ethnocentrism scale. Communication Research Reports, 14, 385-398. 
Potter, W. J. 2003. The 11 myths of media violence. Thousand Oaks, CA: Sage.

Shipper, A.W. 2005. Criminals or Victims? The Politics of Illegal Foreigners in Japan. Journal of Japanese Studies, 31, 299-327.

Sugimoto, Y. 1999. Making Sense of Nihonjinron. Thesis Eleven, 57, 81-96.

Sumner, W. G. 1906. Folkways. Boston, MA: Ginn.

The Lion King. 2011. Retrieved June $7^{\text {th }} 2011$ from http://en.wikipedia.org/wiki/The Lion_King

Thomas, G. 1974. Mass media and minority socialization: conceptualizing the process. Paper presented at the annual meeting of the Association for Education in Journalism. August 18-21. San Diego, CA.
Unknown Author. Socialization. Retrived 4 June 2011 from http://anthro.palomar.edu/social/soc_1. htm

Velkley, R. 2002. The Tension in the Beautiful: On Culture and Civilization in Rousseau and German Philosophy. Being after Rousseau: Philosophy and Culture in Question. (Pp. 11-30). The University of Chicago Press.

Warner, J. 2004. Pokemon Seizures Linked to Epilepsy, Not TV WebMD. Retrived 12 July from http:// my.webmd.com/content/Article/91/100966. html

Wilcox, B. 2004. TV's effect on children's behavior. November 15 . TCOM. 